\title{
Resistance of maize landraces from Brazil to fall armyworm (Lepidoptera: Noctuidae) in the winter and summer seasons
}

\author{
Eduardo Neves Costa ${ }^{1, *}$ (D), Marcos Gino Fernandes ${ }^{1,2}$ (D), \\ Pablo Henrique Medeiros ${ }^{2}$ iD, Bruna Moura Dias Evangelista ${ }^{1}$ \\ 1. Universidade Federal da Grande Dourados - Faculdade de Ciências Agrárias - Programa de Pós-Graduação em \\ Agronomia - Dourados (MS), Brazil. \\ 2. Universidade Federal da Grande Dourados - Faculdade de Ciências Biológicas e Ambientais - Programa de \\ Pós-Graduação em Entomologia e Conservação da Biodiversidade - Dourados (MS), Brazil.
}

\begin{abstract}
The fall armyworm (Spodoptera frugiperda) is a major maize (Zea mays L.) pest in Brazil, whose larvae cause losses from plant emergence to harvesting stage. This pest has been controlled almost exclusively with chemical insecticides and Bt plants (transgenics); however, resistance evolution has been detected to these two control tactics. Therefore, alternative control tactics are needed for management and control of the fall armyworm. Thus, this study aimed to evaluate the resistance of maize landraces from Brazil to larvae of this herbivore in the winter and summer seasons, studying also the occurrence of the predator Doru luteipes (Dermaptera: Forficulidae). The variety Pérola had the highest resistance levels to fall armyworm in the summer season, with lower values of leaf injury, number of infested plants, and number of larvae. Conversely, this variety did not express resistance to the pest in winter. Doru luteipes was found abundantly in the summer season, showing no differences between varieties. This is the first study to evaluate the resistance of maize landraces from Brazil to fall armyworm in the winter and summer seasons. The next step is the molecular characterization of the variety Pérola, as well as evaluating its effects on the most common natural enemies of the pest in Brazil, such as the predator D. luteipes and the egg parasitoid Trichogramma pretiosum (Hymenoptera: Trichogrammatidae). These results may assist future maize breeding programs aimed at developing cultivars and hybrids resistant to the pest, and hence reducing agriculture's dependence on chemical insecticides and transgenic plants.
\end{abstract}

Key words: Zea mays L., integrated pest management, plant resistance to insects, Spodoptera frugiperda.

\author{
Received: \\ Jan. 24, 2020 \\ Accepted: \\ Apr. 14, 2020 \\ Section Editor: \\ Luís Garrigós Leite \\ ${ }^{*}$ Corresponding author: \\ costa_ne@yahoo.com.br
}

\section{INTRODUCTION}

Maize (Zea mays L.) (Cyperales: Poaceae) is one of the world's most important crop plants (Beyene et al. 2016). This plant species has a broad genetic diversity, and therefore it is highly adaptable and responsive to selective pressure. As a result, maize has been grown from the tropics to Southern Canada, a wide biogeographical range that displays high diversity in soil composition, climate, day length, and elevation (Neuffer 1982).

This important crop has had its productivity threatened by different insect pests. The fall armyworm [Spodoptera frugiperda (J. E. Smith)] (Lepidoptera: Noctuidae) is a major pest of maize as well as other crops in the Americas (Oliveira 
et al. 2014; Nagoshi et al. 2015). The larval feeding on maize plants causes yield reductions of up to $60 \%$ depending on severity of the infestations, crop stage development, sowing period, region, genotype, and agricultural practices. This pest attack may occur from seedling emergence to reproductive phase (Cruz 2008; Cruz et al. 2013).

Control of fall armyworm larvae has been historically performed with sprays of insecticides; however, several cases of resistance evolution have limited their effectiveness (Carvalho et al. 2013). In contrast, transgenic maize hybrids that express insecticidal proteins of Bacillus thuringiensis (Bt maize) have been a widely adopted alternative to insecticides for controlling this insect in Brazil. Nevertheless, most $B t$ hybrids have lost efficacy to control the pest within three years after commercial release (Fatoretto et al. 2017).

In this context, host plant resistance (HPR) is a relevant tool to consider for implementation in the integrated pest management (IPM) programs. Host plant resistance is an efficient and environmentally friendly mode of controlling insects (Dogimont et al. 2010), and it is commonly segmented into three categories: antibiosis, antixenosis, and tolerance (Smith 2005; Smith and Clement 2012). Antibiosis is a resistance category that possess at least one plant characteristic that adversely affects pest growth. The insect may show a lower weight, a delayed developmental period, a lower survival, and reduced rates of fecundity and fertility. Antixenosis exhibits at least one plant characteristic that negatively affects pest behavior. The insect rejects the resistant variety for feeding, oviposition, and/or shelter. Tolerance is a polygenic trait enabling a plant to withstand or recover from pest damage without negatively affecting insect's development or survival. The tolerant variety exhibits a similar yield (or biomass) when compared infested versus uninfested plants (Smith 2005; Smith and Clement 2012; Peterson et al. 2017).

Maize landraces are classified as open-pollinated varieties (OPVs), and hence they underwent long-term natural and artificial selection in the past centuries. A great number of these materials have arisen over time, selected by farmers according to the adaptation to the environmental conditions (Cömertpay et al. 2012). Landraces might possess novel favorable alleles for agronomic traits such as yield, tolerance to abiotic stress, and resistance to arthropod pests (Harlan 1975; Zeven 1998). Knowing the extent and nature of the available diversity of maize landraces is essential for their potential application in plant breeding and conservation programs (Sharma et al. 2010).

In this study, was tested the hypothesis that the variety Pérola, adopted as a resistance standard for showing resistance in the laboratory and in the greenhouse to fall armyworm (Nogueira et al. 2018) and Diabrotica speciosa (Germar) (Coleoptera: Chrysomelidae) (Costa et al. 2018), would also be resistant to the mentioned lepidopteran species in field conditions. Thus, the objective of this study was to evaluate the resistance to fall armyworm in maize landraces from Brazil in the winter and summer seasons, assessing the occurrence of the predator Doru luteipes (Scudder) (Dermaptera: Forficulidae).

\section{MATERIAL AND METHODS}

\section{Experimental site}

The experiments were performed from June 2018 to January 2019, corresponding to the maize sowings of the winter (sowing on 15 May 2018) and summer (sowing on 10 December 2018) seasons, which were considered separate trials. These experiments were conducted in an experimental area ( $22^{\circ} 19^{\prime}$ South latitude, $54^{\circ} 937^{\prime}$ West longitude, $454 \mathrm{~m}$ altitude) of Federal University of Grande Dourados (Universidade Federal da Grande Dourados - UFGD), Dourados, MS, Brazil.

The climate in the experimental site is classified as Cwa (humid subtropical climate with hot summer and dry winter), because the temperature of the coldest period (June and July) is inferior to $18{ }^{\circ} \mathrm{C}$ and of the hottest month is superior to $29^{\circ} \mathrm{C}$ (Fietz and Fisch 2017). The soil of the experimental site is categorized as dystroferric red latosol (Bergamin et al. 2010).

\section{Cultural practices}

In both sowing periods, the soil was prepared by plowing and harrowing operations. Spacing of $0.45 \mathrm{~m}$ between each row was adopted in the experiments and six seeds were sown per linear meter. Thinning was carried out 20 days after sowing, 
keeping three plants of maize per linear meter. Each plot had four rows (10 m long), totaling $18 \mathrm{~m}^{2}$ of total area and $9 \mathrm{~m}^{2}$ of useful area. The experiment total area was $288 \mathrm{~m}^{2}$.

Four hundred and fifty $\mathrm{kg} \cdot \mathrm{ha}^{-1}$ of the formula $00-20-20$ (N-P-K) was used for crop fertilization, with an additional $90 \mathrm{~kg} \cdot \mathrm{ha}^{-1}$ of $\mathrm{N}$ in urea form. No chemical insecticides and fungicides were used for pest control and the plots were irrigated whenever necessary. Manual weeding was done at the V3 (three fully expanded leaves) maize vegetative stage according to the Ritchie scale (Ritchie et al. 1993).

A randomized block experimental design was used, constituted by four treatments (maize landraces) and three sampling dates. Four blocks were used as replicates in each growing season.

\section{Maize landraces}

Four maize landrace varieties were assessed in the experiments performed during the winter and summer seasons: Pérola (resistance standard), Asteca Palha Roxa (resistant), Asteca Amarelo (susceptible), and Milho Roxo (susceptible), selected according with the results obtained in previous laboratory and greenhouse experiments and seeds availability. The variety Pérola was adopted as resistance standard according to earlier laboratory and greenhouse results with fall armyworm (Nogueira et al. 2018) (compared to other seven genotypes) and D. speciosa (Costa et al. 2018) (compared to other 18 genotypes).

\section{Assessment methodology}

In the winter season, the evaluations were performed at the $\mathrm{V} 4, \mathrm{~V} 6$, and $\mathrm{V} 8$ vegetative stages. In the summer season, the evaluations were done at the V6, V7, and V8 vegetative stages. The maize plants were assessed from V4 to V8 vegetative stages because this is the period in which maize plants are more susceptible to fall armyworm larval feeding (Cruz 1995). In general, this period is extremely critical for the formation of maize ears and consequently in the final yield of the crop (Cruz and Turpin 1982). In summer, evaluations started at V6 stage because the pest was not found at V4 or V5 stages.

Five maize plants of the two central rows of every plot were sampled on each date, totaling 10 sampled plants per plot. The evaluated plants were randomly chosen before arriving in the field (determined in the laboratory). The maize whorl was removed from the plant, and then opened to evaluate the presence of fall armyworm larvae and $D$. luteipes. Data were expressed as total number of larvae, leaf injury rating (Davis et al. 1992), number of infested plants (injured whorl), and number of individuals of the predator D. luteipes. The 1-9 Davis scale (Davis et al. 1992) was used to evaluate leaf injury rating, whereby a score of 1 indicates no damage up to three very small injuries on maize whorl and a score of 9 indicates whorl and expanded leaves almost or totally destroyed. Each of the five plants of the two central rows in each plot were rated for injury and then an average was calculated.

With the objective of evaluating the performance of the varieties in practical terms, a figure was built to check whether the varieties would show $\geq 20 \%$ plants with an injury rating $\geq 3$, the control level established by the Brazilian Association of Seeds and Seedlings (Associação Brasileira de Sementes e Mudas) (ABRASEM 2014).

\section{Statistical Analysis}

Data on the leaf injury caused by the larval feeding of fall armyworm were analyzed using repeated measures analysis of variance followed by the Tukey's test at $5 \%$ probability. The variety and the sampling time were considered the fixed factors, whilst the four replications within each cropping season were considered the random factor. The count data (number of infested plants, number of fall armyworm larvae, and number of $D$. luteipes individuals) were analyzed using the generalized linear model (Poisson regression), and the means separated by the Tukey's test at $5 \%$ probability. All analyses were performed using the statistical software R(R Core Team 2019). 


\section{RESULTS AND DISCUSSION}

\section{Winter season}

No significant differences were observed for leaf injury considering variety $(F=2.15 ; \mathrm{df}=3,9 ; p=0.5419)$ (values ranged from 3.15 to 3.84$)$, sampling time ( $F=0.08 ; \mathrm{df}=3,9 ; p=0.7720)$ (variation of 2.83 to 4.77 for leaf injury rating), or the interaction between variety versus sampling time $(F=0.72 ; \mathrm{df}=3,9 ; p=0.8687)$. Statistical differences were not found considering the number of fall armyworm larvae at V4 stage $\left(X^{2}=1.55 ; \mathrm{df}=3,9 ; p=0.6697\right)$ (from 6.25 to 8.25 larvae), at V6 stage $\left(X^{2}=3.74 ; \mathrm{df}=3,9 ; p=0.2913\right)$ (from 4.25 to 7.50 larvae), or at V8 stage $\left(X^{2}=2.45 ; \mathrm{df}=3,9 ; p=0.4845\right)$ (from 0.75 to 2.00 larvae). However, a marginally significant difference (i.e. statistical result with a $P$ value near the standard criterion of $p=0.05)$ was recorded for number of infested plants $\left(X^{2}=7.03 ; \mathrm{df}=3,9 ; p=0.0708\right)$, which had values between 4.50 (variety Pérola) to 9.00 (variety Milho Roxo) infested plants. Because no significant differences were noted in the winter season, the statistical details are not shown.

In this study, it was evaluated the resistance of the variety Pérola (compared to other three varieties) in the summer and winter seasons, popularly known as first and second crops, respectively. In Brazil, maize is cultivated in these two different cropping seasons, which show differences regarding abiotic factors as temperature, light length, and relative humidity, variables that can affect plant resistance. For example, the duration, quantity, and quality of light have each been shown to affect the expression of plant resistance to arthropods (Smith 2005).

The resistance of the variety Pérola was not expressed in the winter season. It is found in the literature some examples in which the resistance was not expressed when plants were cultivated in short-day periods. For instance, Kennedy et al. (1981) found that Manduca sexta (L.) (Lepidoptera: Sphingidae) larvae fed on plants of Lycopersicon hirsutum f. glabratum grown under long-day condition displayed greater mortality than larvae fed on leaves from plants grown under shortday condition. Similarly, Patterson et al. (1994) revealed that resistance of strawberry (Fragaria ananassa Duch) plants to Tetranychus urticae Koch (Acari: Tetranychidae) is greater in plants cultivated under long-day condition compared to shortday regime. Smith (2005) mentioned that the higher resistance levels observed under long-day regime occur as a result of a greater plant toxin production. Therefore, it is important to take care when growing resistant varieties in the winter season (non-preferential season), because their resistance expression can be compromised.

Overall, when the plants are cultivated in winter they are subjected to adverse environmental conditions, for example lower temperatures, contributing to a reduction in the expression of genes associated with the resistance to insect pests (Smith 2005). In this study, the average temperature observed in winter was $20.9^{\circ} \mathrm{C}$ (Fig. 1A), whereas in summer the average temperature was $27.2^{\circ} \mathrm{C}$ (Fig. 1B). Thus, the low temperatures observed in winter may have inhibited the expression of resistance of the variety Pérola.

In winter, there was a greater number of fall armyworm-infested plants than in summer. Perhaps this might be explained by the rare occurrence of natural enemies in winter (what did not allow us to record their population), especially D. luteipes, an efficient predator of the pest (Reis et al. 1988). Ni et al. (2014) inferred that the greater abundance and diversity of predators in 2010 than 2009 (summer experiments) might have contributed to a lower level of maize leaf injury caused by this pest on all varieties examined in 2010. Based on the current study data, it is suggested the maize cultivation in winter may result in greater leaf damage and consequent economic losses to growers whether efficient control tactics are not available.

\section{Summer season}

The variety Pérola showed the lowest value of leaf injury rating $(F=13.49 ; \mathrm{df}=3,33 ; p=0.0037)$ compared to the varieties Asteca Amarelo and Asteca Palha Roxa (Fig. 2). There were no statistical differences for leaf injury rating when considering the sampling date $(F=2.07 ; \mathrm{df}=2,33 ; p=0.1500)$, with a variation from 1.93 to 2.27 of leaf injury, nor for the interaction between variety versus sampling date $(F=1.13 ; \mathrm{df}=6,33 ; p=0.7697)$. The leaf injury recorded for the variety Pérola in summer (1.6) was lower than the leaf injury exhibited by the most resistant varieties shown by Ni et al. (2014) 


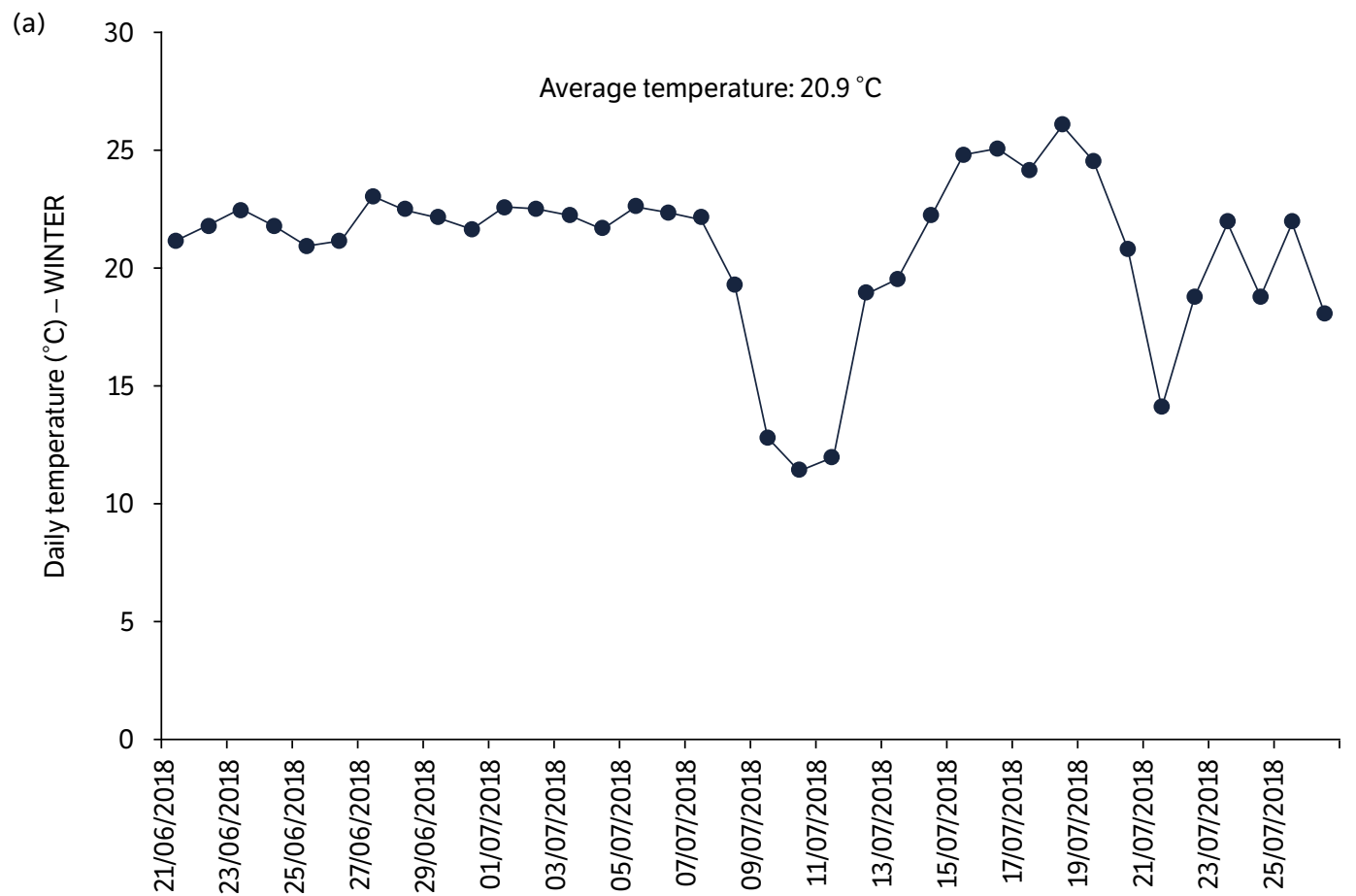

(b)

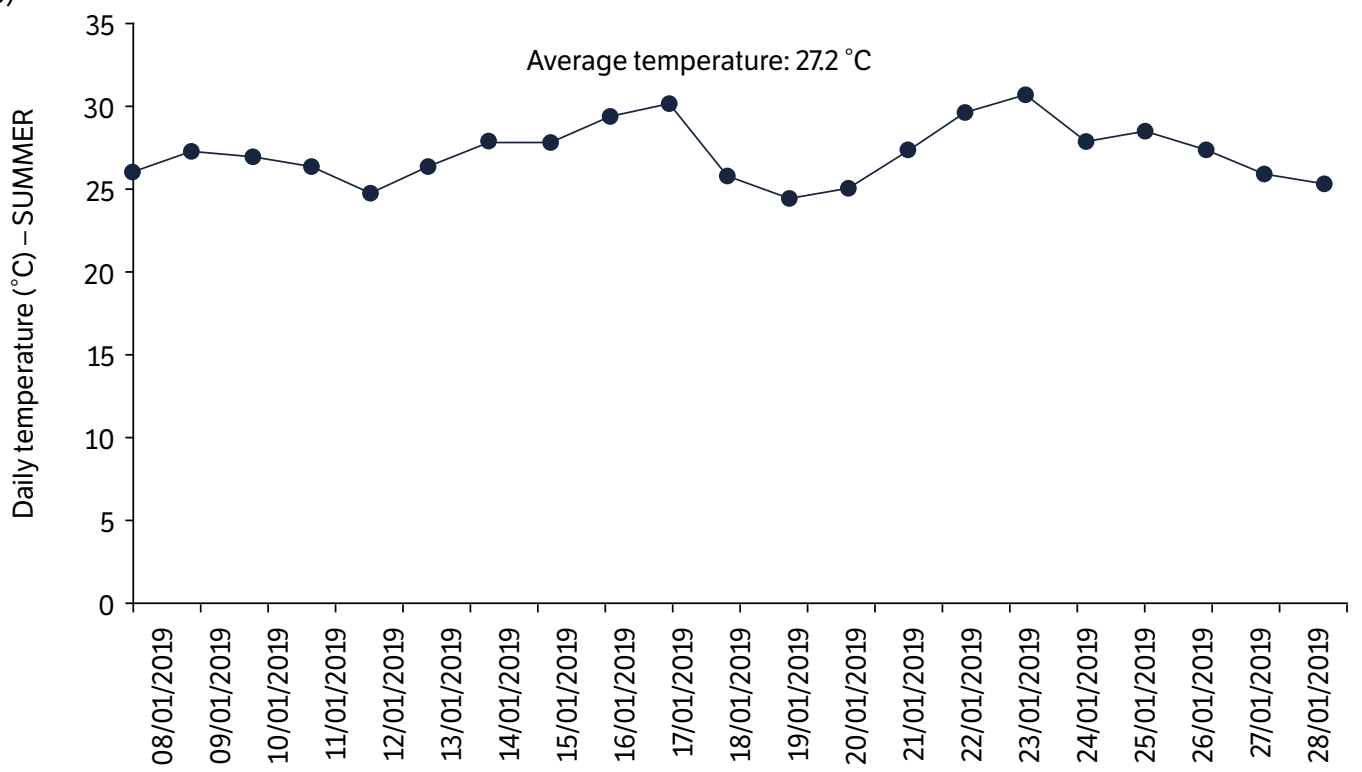

Source: Embrapa Agropecuária Oeste.

Figure 1. Daily temperature recorded during conduction of the experiments in the winter (a) and summer (b) seasons.

(injury rating from 3.0 to 5.0), in a summer season study performed in 2009 at Tifton, GA, USA. This comparison provides an additional parameter to understand the potential of the variety Pérola as an important resistance source to manage fall armyworm infestations.

At V6 stage, the variety Pérola had a lower number of infested plants $\left(X^{2}=11.95 ; \mathrm{df}=3,9 ; p=0.0076\right)$ than the varieties Asteca Amarelo and Milho Roxo (Table 1). However, no statistical differences were registered for number of infested plants at V7 $\left(X^{2}=3.64 ; \mathrm{df}=3,9 ; p=0.3031\right)$ and V8 stages $\left(X^{2}=2.65 ; \mathrm{df}=3,9 ; p=0.4485\right)$ (Table 1$)$.

Differences were not found concerning the number of fall armyworm larvae on V6 plants $\left(X^{2}=3.37 ; \mathrm{df}=3,9 ; p=0.3381\right)$, although marginally significant differences were observed for V7 plants $\left(X^{2}=7.49 ; \mathrm{df}=3,9 ; p=0.0578\right)$, when the variety 


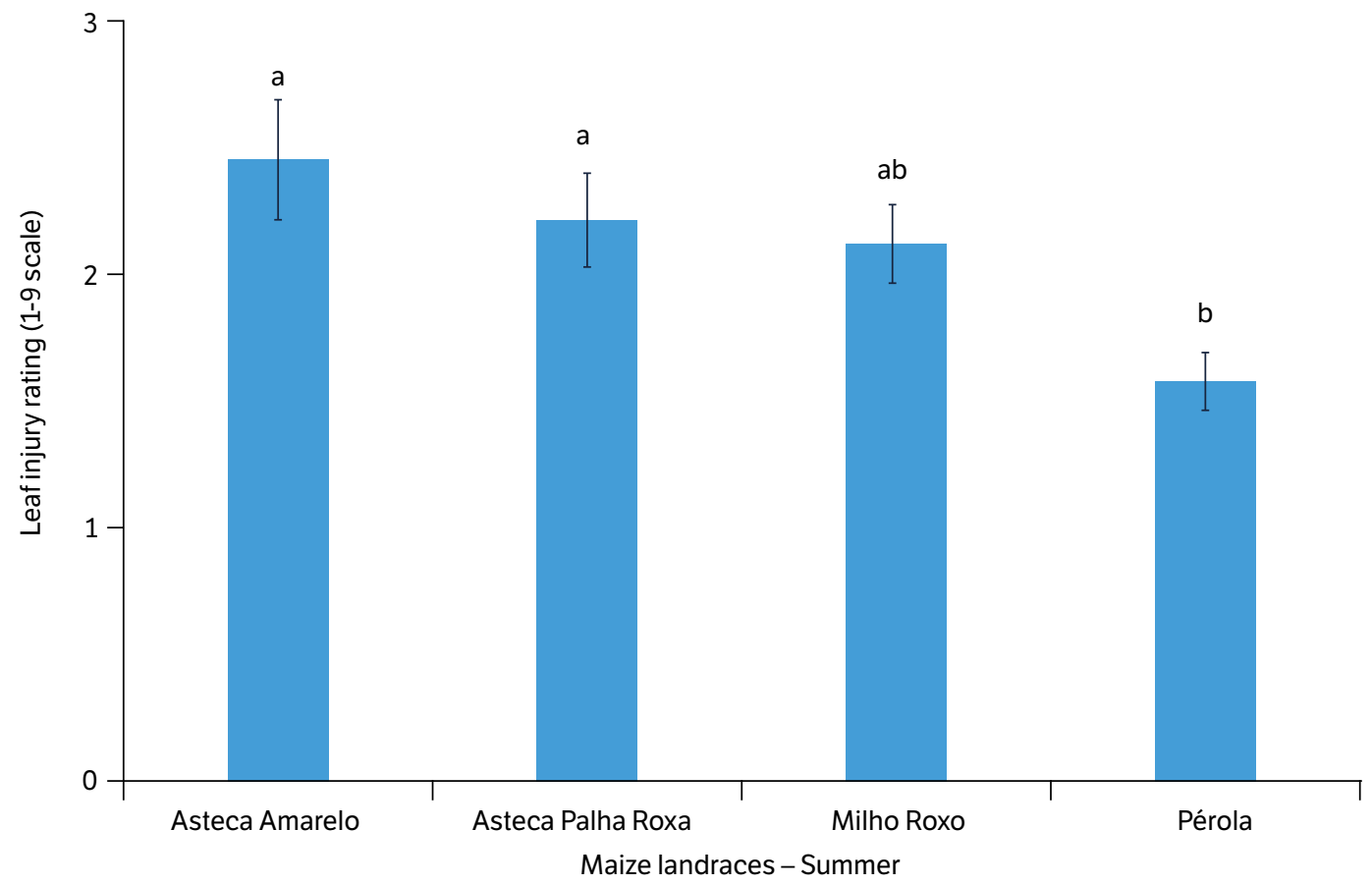

Figure 2. Leaf injury rating (mean \pm SE) of maize landrace varieties exposed to fall armyworm larvae in the summer season. Means followed by the same letter above bars did not differ significantly by Tukey's test at $5 \%$ probability (repeated measures ANOVA).

Table 1. Number of infested plants, fall armyworm (FAW) larvae, and individuals of Doru luteipes (mean \pm SE) in the summer cropping season.

\begin{tabular}{|c|c|c|c|}
\hline \multirow{2}{*}{ Variety } & \multicolumn{3}{|c|}{ V6 plants } \\
\hline & Infested plants (n) & FAW larvae (n) & Doru luteipes (n) \\
\hline Asteca Amarelo & $5.00 \pm 1.96 a$ & $2.25 \pm 1.44 \mathrm{a}$ & $4.25 \pm 1.70 \mathrm{a}$ \\
\hline Asteca Palha Roxa & $4.50 \pm 1.66 \mathrm{ab}$ & $3.50 \pm 2.18 a$ & $4.75 \pm 0.85 a$ \\
\hline Milho Roxo & $5.75 \pm 1.25 a$ & $2.50 \pm 1.50 \mathrm{a}$ & $4.50 \pm 1.50 \mathrm{a}$ \\
\hline Pérola & $1.50 \pm 0.29 b$ & $1.50 \pm 0.29 a$ & $6.50 \pm 1.71 \mathrm{a}$ \\
\hline \multirow{2}{*}{ Variety } & \multicolumn{3}{|c|}{ V7 plants } \\
\hline & Infested plants (n) & FAW larvae (n) & Doru luteipes (n) \\
\hline Asteca Amarelo & $5.75 \pm 0.75 a$ & $4.00 \pm 0.41 a$ & $10.00 \pm 1.83 a$ \\
\hline Asteca Palha Roxa & $4.75 \pm 1.03 a$ & $1.75 \pm 0.48 a$ & $6.25 \pm 0.75 a$ \\
\hline Milho Roxo & $4.75 \pm 0.95 a$ & $3.00 \pm 0.71 a$ & $8.00 \pm 1.58 a$ \\
\hline Pérola & $3.00 \pm 0.58 a$ & $1.25 \pm 0.48 a$ & $5.25 \pm 1.44 a$ \\
\hline \multirow{2}{*}{ Variety } & \multicolumn{3}{|c|}{ V8 plants } \\
\hline & Infested plants (n) & FAW larvae (n) & Doru luteipes (n) \\
\hline Asteca Amarelo & $5.75 \pm 1.25 a$ & $2.25 \pm 1.60 a b$ & $8.50 \pm 1.19 a$ \\
\hline Asteca Palha Roxa & $5.75 \pm 1.75 a$ & $5.50 \pm 1.71 \mathrm{a}$ & $9.00 \pm 1.41 \mathrm{a}$ \\
\hline Milho Roxo & $4.25 \pm 1.03 a$ & $2.75 \pm 0.25 a b$ & $10.00 \pm 1.87 a$ \\
\hline Pérola & $3.75 \pm 0.48 a$ & $1.50 \pm 0.29 b$ & $10.25 \pm 2.95 \mathrm{a}$ \\
\hline
\end{tabular}

Means followed by different letters within columns are significantly different by Tukey's test at $5 \%$ probability (Poisson regression). ( $\mathrm{n}=\mathrm{number)}$.

Pérola showed one of the lowest number of larvae. However, this trend was confirmed when evaluating V8 plants $\left(X^{2}=11.26\right.$; $\mathrm{df}=3,9 ; p=0.0104)$, with the variety Pérola displaying a lower number of fall armyworm larvae compared to the variety Asteca Palha Roxa (Table 1). 
Due to the fact that plants of the variety Pérola exhibited lower values of leaf injury rating, number of infested plants, and number of fall armyworm larvae, it is possible to affirm that this variety expressed resistance to the pest in summer, the preferential growing season for maize in Brazil.

There are few studies published on resistance of maize landraces from Brazil to insect pests. One study evaluated the oviposition preference and antibiosis to fall armyworm in different maize landrace varieties, in laboratory and greenhouse assays (Nogueira et al. 2018). The authors found that the variety Pérola affected the oviposition preference, and larvae fed on this variety consumed a lower amount of leaves and had longer development time and lower survival compared to seven other landraces. Another study assessed resistance to Diabrotica speciosa in 19 maize genotypes (17 landraces and 2 cultivars), and concluded that variety Pérola was one of the most resistant to the pest for delaying the maturation period from larva to adult and decreasing survivorship (Costa et al. 2018). These laboratory and greenhouse studies were very important to classify the variety Pérola as resistant to insect pests. However, there was a gap regarding studies on resistance of the variety Pérola with evaluations of leaf injury rating in field conditions. It is important to evaluate the leaf injury rating because this variable is commonly used to determine whether fall armyworm has reached its control level in maize crops, as defined by programs of integrated pest management.

According to ABRASEM (2014), it is necessary to control fall armyworm larvae when 20\% (or more) of the evaluated plants show injury rating $\geq 3$. In summer, plants of the variety Pérola showed a fall armyworm population level below this control level at V6 and V7 stages (Fig. 3). Conversely, the other varieties had an infestation level above the control level in all evaluations (considering a total of 40 plants evaluated in each vegetative stage). Thus, according to this recommendation, plants expressing resistance of the variety Pérola will be more independent of exogenous intervention (e.g., insecticide application) than the modern commercial cultivars. In a context of integrated pest management, the variety Pérola should be classified as moderately resistant, because the control level for the pest was observed at least in one of the evaluations. Smith (2005) affirmed that plants expressing moderate resistance levels exhibit several advantages, for example, it is much more difficult to occur insect resistance evolution and negative impacts on natural enemies compared to varieties expressing high resistance levels.

It may be inferred that the resistance of the variety Pérola to fall armyworm is strongly associated to antixenosis (lower number of larvae), corroborating a previous greenhouse study (Nogueira et al. 2018), now in a more realistic condition (agricultural field). Due to the fact that the variety Pérola expressed resistance to fall armyworm larval feeding using detached leaf sections (Nogueira et al. 2018), we suggest its resistance is constitutively governed by the presence of pre-formed resistance factors, such as toxic allelochemicals and structures that stiffen the leaf cell wall (lignin, cellulose, silicon etc.). The knowledge that constitutive genes are playing an important role for the resistance of the variety Pérola may be very useful for supporting plant breeding programs.

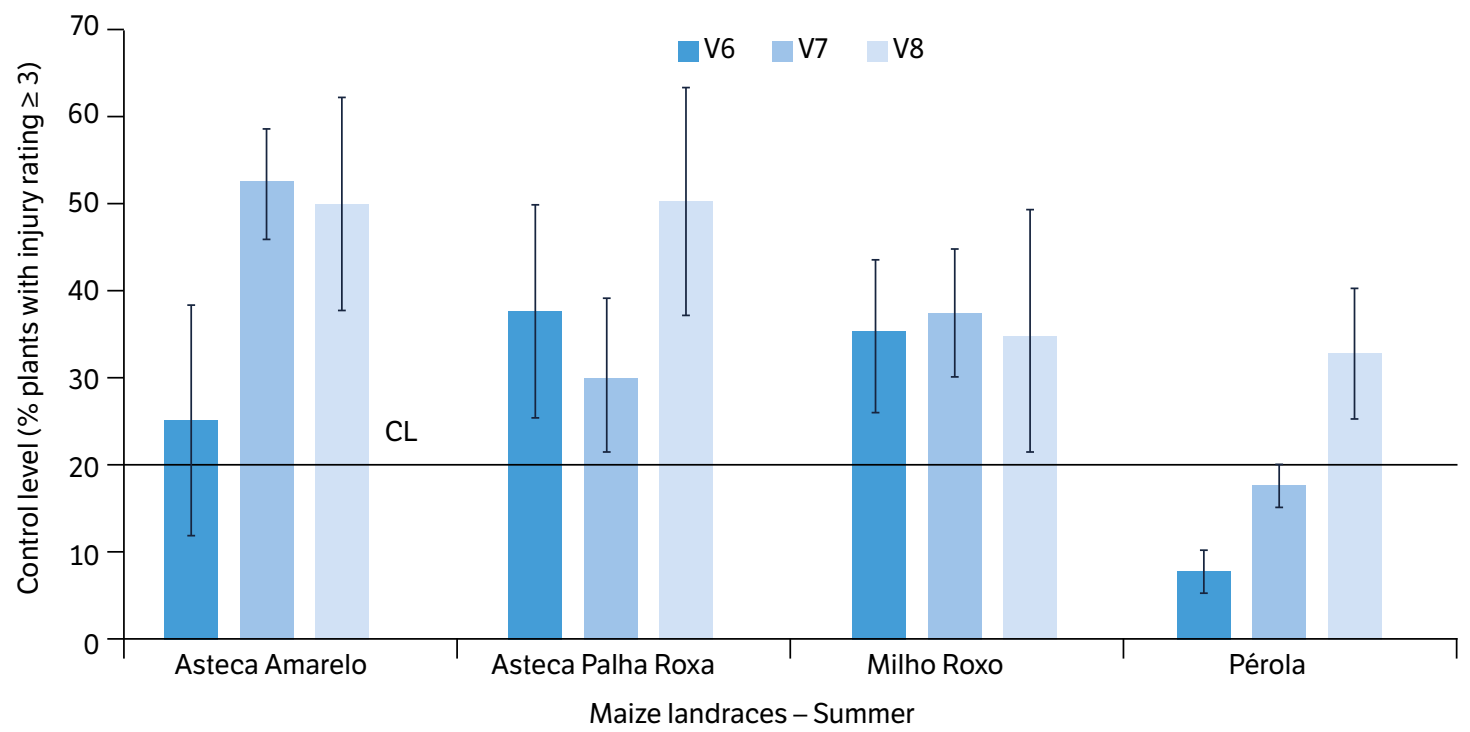

Figure 3. Percentage of plants of different maize landrace varieties displaying a leaf injury rating $\geq 3$ in the summer season. $\mathrm{CL}=$ control level. 
With respect to the number of individuals of the predator $D$. luteipes, significant differences were not recorded between varieties when assessing plants at $\mathrm{V} 6$ stage $\left(X^{2}=2.37 ; \mathrm{df}=3,9 ; p=0.4982\right)$, at $\mathrm{V} 7$ stage $\left(X^{2}=7.02 ; \mathrm{df}=3,9 ; p=0.0714\right)$, or at V8 stage $\left(X^{2}=0.87 ; \mathrm{df}=3,9 ; P=0.8323\right)$ (Table 1). Thus, it seems that the resistance of the variety Pérola did not exert a negative impact on the population of $D$. luteipes, although detailed laboratory studies are required to affirm that this predator is not affected when fed on fall armyworm larvae previously fed on variety Pérola.

\section{CONCLUSION}

The variety Pérola may be promising for protection of maize crops. Further studies are necessary to investigate the resistance of the variety Pérola to fall armyworm larvae in the winter season, perhaps with an earlier sowing time than May. Investigations on which genes are associated to the resistance of the variety Pérola and their effects on natural enemies will contribute to future maize breeding programs, with the aim of developing fall armyworm-resistant cultivars and hybrids and hence reducing agriculture's dependence on synthetic insecticides and transgenic plants.

\section{ACKNOWLEDGMENTS}

The authors are thankful to Mr. Valter Loeschner from Ministry of Agriculture Livestock and Food Supply (MAPA) and Mr. André Emílio Jantara from Agricultura Familiar e Agroecologia (AS-PTA) for providing the maize landraces seeds; and Coordenação de Aperfeiçoamento de Pessoal de Nível Superior (CAPES) for granting a Post-Doctoral Scholarship (PNPD) to the first author.

\section{AUTHOR'S CONTRIBUTION}

Conceptualization, Costa E. N.; Methodology, Costa E. N. and Fernandes M. G.; Investigation, Costa E. N., Medeiros P. H. and Evangelista B. M. D.; Writing - Original Draft, Costa E. N.; Writing - Review and Editing, Costa E. N.; Funding Acquisition, Costa E. N.; Resources, Costa E. N. and Fernandes M. G.; Supervision, Fernandes M. G.

\section{FUNDERS}

Coordenação de Aperfeiçoamento de Pessoal de Nível Superior

[https://doi.org/10.13039/501100002322]

\section{REFERENCES}

[ABRASEM] Associação Brasileira de Sementes e Mudas. (2014). Boas práticas agronômicas aplicadas a plantas geneticamente modificadas resistentes a insetos. Brasília: ABRASEM. [Accessed Jun. 9 2020]. Available at: https://boaspraticasagronomicas.com.br/ wp-content/uploads/2015/12/Apresentacao_Abrasem_2014_ok.pdf

Bergamin, A. C., Vitorino, A. C. T., Franchini, J. C., Souza, C. M. A. and Souza, F. R. (2010). Compactação em um latossolo vermelho distroférrico e suas relações com o crescimento radicular do milho. Revista Brasileira de Ciência do Solo, 34, 681-691. https://doi. org/10.1590/S0100-06832010000300009 
Beyene, Y., Semagn, K., Crossa, J., Mugo, S., Atlin, G. N., Tarekegne, A., Meisel, B., Sehabiague, P., Vivek, B. S., Oikeh, S., Alvarado, G., Machida, L., Olsen, M., Prasanna, B. M. and Bänziger, M. (2016). Improving maize grain yield under drought stress and non-stress environments in Sub-Saharan Africa using marker-assisted recurrent selection. Crop Science, 56, 344-353. https://doi.org/10.2135/ cropsci2015.02.0135

Carvalho, R. A., Omoto, C., Field, L. M., Williamson, M. S. and Bass, C. (2013). Investigating the molecular mechanisms of organophosphate and pyrethroid resistance in the fall armyworm Spodoptera frugiperda. PLoS One, 8, e62268. https://doi.org/10.1371/journal.pone.0062268

Cömertpay, G., Baloch, F. S., Kilian, B., Ülger, A. C. and Özkan, H. (2012). Diversity assessment of Turkish maize landraces based on fluorescent labelled SSR markers. Plant Molecular Biology Reporter, 30, 261-274. https://doi.org/10.1007/s11105-011-0332-3

Costa, E. N., Nogueira, L., Souza, B. H. S., Ribeiro, Z. A., Louvandini, H., Zukoff, S. N. and Boiça Júnior, A. L. (2018). Characterization of antibiosis to Diabrotica speciosa (Coleoptera: Chrysomelidae) in Brazilian maize landraces. Journal of Economic Entomology, 111, 454462. https://doi.org/10.1093/jee/tox350

Cruz, I. (1995). A lagarta-do-cartucho na cultura do milho. Sete Lagoas: EMBRAPA-CNPMS. [Circular técnica 21] [Accessed Jun. 09, 2020]. Available at: http://www.infoteca.cnptia.embrapa.br/infoteca/handle/doc/475779

Cruz, I. (2008). Manejo de pragas da cultura do milho. In J. C. Cruz, D. Karam. M. A. R. Monteiro and P. C. Magalhães (Eds), A cultura do milho (p. 303-362). Sete Lagoas: Embrapa Milho e Sorgo. [Accessed Jun. 9 2020]. Available at: https://www.bdpa.cnptia.embrapa. br/consulta/busca?b=pc\&id=491710\&biblioteca=vazio\&busca=autoria:\%22CRUZ,\%201.\%22\&qFacets=autoria:\%22CRUZ,\%20 I.\%22\&sort=\&paginacao=t\&paginaAtual $=4$

Cruz, I. and Turpin, F. T. (1982). Efeito da Spodoptera frugiperda em diferentes estádios de crescimento da cultura de milho. Pesquisa Agropecuária Brasileira, 17, 355-359.

Cruz, I., Valicente, F. H., Viana, P. A. and Mendes, S. M. (2013). Risco potencial das pragas de milho e de sorgo no Brasil [Documentos 150]. Sete Lagoas: Embrapa Milho e Sorgo. [Accessed Jun. 9 2020]. Available at: https://www.embrapa.br/busca-de-publicacoes/-/ publicacao/962995/risco-potencial-das-pragas-de-milho-e-de-sorgo-no-brasil

Davis, F. M., Ng, S. S. and Williams, W. P. (1992). Visual rating scales for screening whorl-stage corn for resistance to fall armyworm [MAFES. Technical Bulletin 186]. Mississippi: MAFES/MSU. [Accessed Jun. 9 2020]. Available at: https://www.bdpa.cnptia.embrapa. br/consulta/busca?b=ad\&id=236077\&biblioteca=vazio\&busca=autoria:\%22DAVIS,\%20F.\%20M.\%22\&qFacets=autoria:\%22DAVIS,\%20 F.\%20M.\%22\&sort=\&paginacao=t\&paginaAtual=1

Dogimont, C., Bendahmane, A., Chovelon, V. and Boissot, N. (2010). Host plant resistance to aphids in cultivated crops: Genetic and molecular bases and interactions with aphid populations. Comptes Rendus Biologies, 333, 566-573. https://doi.org/10.1016/j. crvi.2010.04.003

Fatoretto, J. C., Michel, A. P., Silva Filho, M. C. and Silva, N. (2017). Adaptive potential of fall armyworm (Lepidoptera: Noctuidae) limits Bt trait durability in Brazil. Journal of Integrated Pest Management, 8, 17. https://doi.org/10.1093/jipm/pmx011

Fietz, C. R. and Fisch, G. F. (2017). O clima da região de Dourados, MS. Dourados: Embrapa Agropecuária Oeste. [Documentos 92] [Accessed Jun. 9 2020]. Available at: https://www.embrapa.br/busca-de-publicacoes/-/publicacao/250759/o-clima-da-regiao-de-dourados-ms

Harlan, J. R. (1975). Our vanishing genetic resources. Science, 188, 617-621. https://doi.org/10.1126/science.188.4188.617

Kennedy, G. G., Yamamoto, R. T., Dimock, M. B., Williams, W. G. and Bordner, J. (1981). Effect of day length and light intensity on 2-tridecanone levels and resistance in Lycopersicon hirsutum f. glabratum to Manduca sexta. Journal of Chemical Ecology, 7, 707-716. https://doi.org/10.1007/BF00990303

Nagoshi, R. N., Rosas-García, N. M., Meagher, R. L., Fleischer, S. J., Westbrook, J. K., Sappington, T. W., Hay-Roe, M., Thomas, J. M. G. and Murúa, G. M. (2015). Haplotype profile comparisons between Spodoptera frugiperda (Lepidoptera: Noctuidae) populations 
from Mexico with those from Puerto Rico, South America and the United States and their implications to migratory behavior. Journal of Economic Entomology, 108, 135-144. https://doi.org/10.1093/jee/tou044

Neuffer, M. G. (1982). Growing maize for genetic purposes. In W. F. Sheridan (Ed), Maize for biological research (p. 19-30). Grand Forks: University Press.

Ni, X., Xu, W., Blanco, M. H. and Williams, W. P. (2014). Evaluation of fall armyworm resistance in maize germplasm lines using visual leaf injury rating and predator survey. Insect Science, 21, 541-555. https://doi.org/10.1111/1744-7917.12093

Nogueira, L., Costa, E. N., Di Bello, M. M., Diniz, J. F. S., Ribeiro, Z. A. and Boiça Júnior, A. L. (2018). Oviposition preference and antibiosis to Spodoptera frugiperda (Lepidoptera: Noctuidae) in Brazilian maize landraces. Journal of Economic Entomology, 112, 939-947. https:// doi.org/10.1093/jee/toy388

Oliveira, C. M., Auad, A. M., Mendes, S. M. and Frizzas, M. R. (2014). Crop losses and the economic impact of insect pests on Brazilian agriculture. Crop Protection, 56, 50-54. https://doi.org/10.1016/j.cropro.2013.10.022

Patterson, C. G., Archbold, D. D., Rodriguez, J. G. and Hamilton-Kemp, T. R. (1994). Daylength and resistance of strawberry foliage to the twospotted spider mite. HortScience, 29, 1329-1331. https://doi.org/10.21273/HORTSCI.29.11.1329

Peterson, R. K. D., Varella, A. C. and Higley, L. G. (2017). Tolerance: the forgotten child of plant resistance. PeerJ, 5, e3934. https://doi. org/10.7717/peerj.3934

R Core Team. (2019). R: a language and environment for statistical computing. Vienna: R Foundation for Statistical Computing. [Accessed Jun. 9 2020]. Available at: http://www.r-project.org/index.html

Reis, L. L., Oliveira, L. J. and Cruz, I. (1988). Biologia e potencial de Doru luteipes no controle de Spodoptera frugiperda. Pesquisa Agropecuária Brasileira, 23, 333-342.

Ritchie, S. W., Hanway, J. J. and Benson, G. O. (1993). How a corn plant develops? Ames: lowa State University of Science and Technology. Sharma, L., Prasanna, B. M. and Ramesh, B. (2010). Analysis of phenotypic and microsatellite-based diversity of maize landraces in India, especially from the North East Himalayan region. Genetica, 138, 619-631. https://doi.org/10.1007/s10709-010-9436-1

Smith, C. M. (2005). Plant resistance to arthropods: molecular and conventional approaches. Dordrecht: Springer. https://doi. org/10.1007/1-4020-3702-3

Smith, C. M. and Clement, S. L. (2012). Molecular bases of plant resistance to arthropods. Annual Review of Entomology, 57, $309-328$. https://doi.org/10.1146/annurev-ento-120710-100642

Zeven, A. C. (1998). Landraces: A review of definitions and classifications. Euphytica, 104,127-139. https://doi.org/10.1023/A:1018683119237 